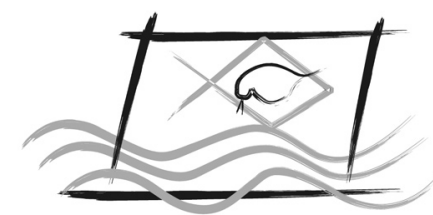

ECOTOX - BRASIL

\title{
Ecotoxicity of Sludges Generated by Textile Industries: a Review
}

\author{
L.S. Gomes ${ }^{1}$, F.A. Silva ${ }^{2}$, S. Barbosa ${ }^{2} \&$ F. Kummrow ${ }^{3 *}$ \\ 'Faculdade de Ciências Farmacêuticas, Universidade Federal de Alfenas - Unifal-MG, \\ Rua Gabriel Monteiro da Silva, 700, CEP 37.130-000, Alfenas-MG, Brasil. \\ ${ }^{2}$ Instituto de Ciências da Natureza, Universidade Federal de Alfenas - Unifal-MG, \\ Rua Gabriel Monteiro da Silva, 700, CEP 37.130-000, Alfenas-MG, Brasil. \\ ${ }^{3}$ Instituto de Ciências Ambientais, Químicas e Farmacêuticas, Universidade Federal de São Paulo (Unifesp), \\ Rua Prof. Arthur Riedel, 275, CEP 09.972-270, Diadema-SP, Brasil.
}

(Received November 10, 2010/Accepted September 06, 2011)

\begin{abstract}
Textile industries consume a large amount of water and use toxic products in its processes. Consequently, they produce and release large volumes of effluents, which, treated, generate great amount of sludge. The final disposal of this sludge remains a challenge, and its ecotoxicological assessment is an important parameter to minimize its impacts. This article reviewed the ecotoxicological tests that have been employed to evaluate the hazard of such sludge. There are few papers in the literature on this issue, as well as a lack of consensus about sample preparation procedures and test organisms to be used. The test organisms most employed are higher plants, bacteria and aquatic organisms. Only one article used earthworms and one, mammals. Composting was efficient for reduction or elimination of the phytotoxicity of textile sludge. Both Daphnia magna and Vibrio fischeri showed adequate sensitivity for sludge acute toxicity evaluation. The endpoint genotoxicity using the Salmonella/ microsome assay seems to be important, because most of the obtained results were positive. More studies are needed to understand the applicability of algae, earthworms and mammals. Efforts are being made to establish a reliable battery of bioassays for ecotoxicological evaluation of such waste.
\end{abstract}

Key words: Textile sludge, bioassays, ecotoxicity, genotoxicity.

Ecotoxicidade de Lodos Gerados por Indústrias Têxteis: uma Revisão da Literatura

\section{Resumo}

Indústrias têxteis consomem grandes quantidades de água e utilizam produtos tóxicos em seus processos. Consequentemente, produzem e lançam grandes volumes de efluentes que, quando tratados, geram grandes quantidades de lodo. A disposição final deste lodo permanece como um desafio e a sua avaliação ecotoxicológica é um parâmetro relevante para minimizar os seus impactos. Este artigo revisou os testes ecotoxicológicos que têm sido empregados para avaliar o perigo desse tipo de resíduo. Há escassez de literatura sobre o tema, assim como falta de consenso sobre os procedimentos de preparo das amostras e organismos testes que devam ser empregados para tal avaliação. Os organismos mais usados foram plantas superiores, bactérias e organismos aquáticos. Apenas um artigo empregou minhocas e outro, mamíferos. A compostagem se mostrou eficiente na redução ou eliminação da fitotoxicidade do lodo têxtil. Tanto Daphnia magna quanto Vibrio fischeri apresentaram sensibilidade adequada para avaliação da toxicidade aguda. O parâmetro genotoxicidade empregando o teste Salmonella/ microssoma parece ter importância, pois a maioria dos resultados encontrados foram positivos. Mais estudos são necessários para entender a aplicabilidade de algas, minhocas e mamíferos. Esforços estão sendo realizados para estabelecer uma bateria de bioensaios adequados à avaliação ecotoxicológica de lodo têxtil.

Palavras-chaves: Lodo têxtil, bioensaios, ecotoxicidade, genotoxicidade.

* Corresponding author: Fábio Kummrow, e-mail: fkummrow@gmail.com; fkummorow@unifesp.br 


\section{INTRODUCTION}

The textile sector uses amounts of water as high as 3,000 $\mathrm{m}^{3}$ day $^{-1}$ and employs toxic products in their industrial processes such as metals, solvents, surfactants and dyes. These processes produce large volumes of effluents that need to be adequately treated before their release into the environment (Dellamatrice \& Monteiro, 2006a, b; Rodrigues \& Pawlowsky, 2007; Arslan-Alaton \& Alaton, 2007; Mathur et al., 2007; Sharma et al., 2007; Abreu et al., 2008). Biological treatment such as activated sludge has been the choice of the majority of the facilities (Kunz et al., 2002). However, this process generates a great quantity of sludge (Kunz et al., 2002) that is basically formed by the excess of biomass and substances that were not degraded during the biological treatment. An industry that consumes $50 \mathrm{~m}^{3}$ of water per hour can generate 1-10 ton of sludge per day in wet basis (Balan \& Monteiro, 2001).

The resulting textile sludge has usually been disposed in landfill or incinerated with high associated costs. Modern waste management practices suggest recycling when possible (Rosa et al., 2007b). Textile biological sludge contain high amounts of organic matter, N, P, K and micronutrients and, therefore, they could be used as fertilizer in soils with poor agricultural productivity (Rosa et al., 2007a) or as soil conditioner in degraded areas (Araújo \& Monteiro, 2005; Araújo et al., 2007). However such sludge may also contain toxic substances such as heavy metals, dyes, other recalcitrant organic compounds, as well as abiotic and biotic transformation products that can negatively impact the soil (Hewitt \& Marvin 2005; Sharma et al., 2007; Rosa et al., 2007b). Terrestrial and aquatic biota, crops and livestock could be exposed to those contaminants and adverse effects could occur.

Because the diversity of chemicals that may possibly be present in this waste it is difficult to determine its toxicity based only on chemical analysis (Araújo et al., 2001; Kapanen \& Itävaara, 2001; Celebi \& Kendir, 2002; Wilke et al., 2008). Toxicity tests can provide additional information about the hazard of those complex mixtures (Kapanen \& Itävaara, 2001; Girotti et al., 2008; Wilke et al., 2008). This article aimed at reviewing how ecotoxicity tests have been employed to evaluate the hazard of sludge generated by textile industries.

\section{RESULTS AND DISCUSSION}

Only twelve articles were found presenting results of ecotoxicity of sludge from textile effluents exclusively. Wilke et al. (2008) had already pointed out that only few attempts have been made to use ecotoxicological tests for the hazard characterization of wastes. We observed that different methods for sample preparation were employed and test organisms such as bacteria, algae, rotifers, microcrustaceans, earthworms, fishes, plants and mammals were used.

\section{Sludge sample preparation}

Appropriate sample preparation is crucial for carrying out toxicity tests that are best performed using whole samples. In general, this can performed with terrestrial test organisms, but for aquatic ones, liquid samples are required. Solvents are used to extract chemicals from solid matrices.

For phytotoxicity evaluation of textile sludge the sample preparation techniques most usually used were: (a) aqueous extraction (leaching or solubilization) (Araújo et al., 2001; Araújo et al., 2005; Araújo \& Monteiro, 2005); (b) sample dilution in a control soil (Araújo et al., 2007; Rosa et al., 2007a, b) and (c) sample in natura (El Hammadi et al., 2007). For aquatic organisms aqueous extracts obtained at natural and acidic $\mathrm{pH}$ were employed (Park et al., 2005, Rodrigues \& Pawlowsky, 2007; Rosa et al., 2007a). For bacteria, depending on the endpoint of the toxicity test either aqueous (Rodrigues \& Pawlowsky, 2007; Rosa et al., 2007a; Park et al., 2005, Mathur et al., 2007) or organic extracts (Umbuzeiro et al., 2004) were used. For earthworms, samples were diluted in control soil (Rosa et al., 2007a). For mammals, Soni et al. (2008) used aqueous extract via oral exposure.

A variety of sample preparation procedures were employed and consequently it is difficult to compare the obtained results. It appears that the choice of the authors was made according to the compatibility of the sample with the test system. Umbuzeiro et al. (2004) compared different extraction procedures before performing the toxicity tests and showed that different extraction procedures have a direct influence in the toxicity response. The use of the international standards such as EN 14735 (2005), as suggested by Kočí et al. (2010), could facilitate the comparison of the toxicity data worldwide.

\section{Toxicity evaluation of textile sludge}

\section{Phytotoxicity}

Phytotoxicity may be described as an intoxication of living plants by substances present in the growth medium, when these substances are taken up and accumulated in plant tissue (Araújo\& Monteiro, 2005; Araújo et al., 2005). In this situation, growth reduction of the aerial parts was the main symptom. The species typically used in phytotoxicity bioassays were Avena sativa, Brassica campestris and Latuca sativa (Parvez et al., 2006), although other species have also been employed, such as Glycine max, Triticum aestivum, Vigna unguiculata, Euruca sativa, Brassica oleracea and Helianthus annuиs (Araújo et al., 2001; Araújo et al., 2005; Araújo \& Monteiro, 2005; Araújo et al., 2007; Rosa et al., 2007a, b; El Hammadi et $a l ., 2007)$. The use of these organisms shows advantages such as the possibility of analyzing several endpoints (germination rate, biomass production, enzymatic activity, among others) for the toxicity evaluation in the same test species, and their low maintenance cost. Seed germination and plant growth are the most usual endpoints for evaluating phytotoxicity. 
Araújo et al. (2001) used soybean (G. max) and wheat ( $T$. aestivum) as test species for evaluating the toxicity of fresh and composted textile sludge. The endpoints observed were seed germination, expressed as the percentage of seeds germinated in the presence of the extracts relative to the total number of seeds germinated in the control, and root elongation, expressed as the percentage of the average root length in the presence of the extracts relative to the average length in the control. The relative seed germination of wheat and soybean was as high as $90 \%$ for all concentrations of composted sludge extracts. Regarding fresh sludge samples, an inhibitory effect on germination was observed, mainly for wheat seeds (only $23 \%$ of germination for the not diluted extract). In relation to root elongation, the results were similar for both species, except for the soybean seeds in relation to the not diluted extract, in which a relative elongation of $161 \%$ was observed. For the fresh sludge extracts, toxicity was observed with root length as endpoint, and wheat was more sensitive. According to the authors such higher sensitivity relates to the lower nutrient content in wheat seed (2 times less than soybean seeds). Plant sensitivity to toxic compounds depends directly on the amount of nutrients reserves found in their seeds (Araújo et al., 2001).

Araújo et al. (2005) evaluated the phytotoxicity of textile sludge which was composted with wood shaves through bioassays with wheat and soybean seedlings. The seedlings were exposed to aqueous extracts (obtained with water and water plus Hoagland's nutritive solution) during 15 days. After that period, the following endpoints were evaluated: toxicity symptoms in the leaves, total dry mass, height of the aerial part, root length, chlorophyll content and peroxidase activity of leaves and roots. The tested sludge concentrations ranged from 0.19 to $152 \mathrm{~g} . \mathrm{L}^{-1}$. Concentrations higher than $19 \mathrm{~g} . \mathrm{L}^{-1}$ led to a significant decrease of the total dry mass, height of the aerial part and root length for both species. The decrease of total dry mass is an important indication of toxicity, which in that study seemed to be related to the presence $\mathrm{Cu}$ and $\mathrm{Zn}$.

The endpoint root elongation was more sensitive than the height of the aerial part when the seedlings were exposed to higher concentrations of the extracts. There was a significant decrease in the root length/height ratio of the aerial part for seedlings of both species exposed to concentrations equal or higher than $38 \mathrm{~g} . \mathrm{L}^{-1}$ (Araújo et al., 2005). Root growth is more affected by heavy metals than the height of the plant aerial parts (Ali et al., 2004).

Regarding biochemical endpoints, both species showed a significant decrease in the chlorophyll content characterized by chlorotic points in the margins until the start of leaf necrosis. The decrease in chlorophyll content causes a simultaneous reduction in net photosynthesis and, as a result, plant growth is reduced. Peroxidase activity increased after the application of the compost both in the roots and in the leaves of both species. Such increase is related to plant growth under stress conditions, and works as a protective barrier against the harmful effect caused by the peroxidation of toxic substances present in the environment. The authors observed a higher increase of enzymatic activity in the roots than in the leaves. Such increase suggests a contribution of this enzyme in the reduction of root growth (Araújo et al., 2005). According to Byl et al. (1994), peroxidase is involved in plant cell growth, and an increase in its activity leads to a reduction in vegetative growth. The authors concluded that root growth and peroxidase activity are the most sensitive endpoints to evaluate the toxicity of sludge (Araújo et al., 2005).

Araújo \& Monteiro (2005) also evaluated composted textile sludge using wheat and soybean. They used aqueous extracts prepared with distilled and with Hoagland solution and the tested concentrations ranged from 0 to 152 g.L. $\mathrm{L}^{-1}$. The authors evaluated seed germination and plant growth. For the evaluation of plant growth, pre-germinated seeds of both species were employed. The seedlings grew under an aerated hydroponics system.

Aqueous extracts prepared with distilled water did not cause any harmful effect on seed germination or root elongation. Aqueous extracts obtained with Hoagland solution and tested with seedlings showed an inhibitory effect on growth. Concentrations equal or above 38 g.L. $\mathrm{L}^{-1}$ decreased the total dry matter production, shoot and root length of soybean and wheat seedlings. Compared to the control, the decrease for soybean were 68 to $76 \%$ for total dry mass, 64 to $81 \%$ for shoot length and 3 to $68 \%$ for root length. For wheat the inhibitory effect was 65 to $72 \%$ for total dry mass, 84 to $92 \%$ for shoot length and 46 to $50 \%$ for root length. (Araújo \& Monteiro, 2005).

The results observed for the hydroponic system indicated that the compost in high concentrations is harmful to both species, mainly observed for the total dry mass endpoint (Araújo \& Monteiro, 2005). According to Kapustka (1997), total dry mass provides the best indication of adverse effects of toxic substances to higher plants.

Araújo et al. (2007) also evaluated the effect of composted textile sludge on growth, nodulation, and nitrogen fixation on soybean and cowpea ( $V$. unguiculata) at two different periods (36 and 63 days after plant emergence). Glutamine synthetase (GS) activity and leghemoglobin content were only evaluated 63 days after emergence. The composted sludge was mixed to a soil with high permeability, low carbon content, small water retention capacity and low fertility.

Toxic effects were observed in soybean plants after 36 days and in the cowpea beans only after 63 days at a $2 x$ application rate of sludge. Except for the soybean, which showed a smaller root and nodules dry weight at the $2 \mathrm{x}$ application rate in 36 days, there were no significant differences in the number or dry mass of the nodules and roots of both soybean and cowpea among the treatments. The composted textile sludge caused no adverse effects on the formation of nodules. This lack of effect was not expected because nodulation is usually suppressed in soils rich in N. GS activity and the leghemoglobin contents were not affected. There was an increase in the nodulation and in the leghemoglobin content in plants growing in soils with a $0.5 \mathrm{x}$ application rate of compost. These results confirm that there is no toxic effect of the compost on $\mathrm{N}$ fixation for both species. After 36 days of plant emergence, there were 
no significant differences in the accumulation of $\mathrm{N}$ by the soybean plants, while the cowpea accumulates more $\mathrm{N}$ when the compost was applied. The authors concluded that the composted textile sludge did not negatively affect the growth, nodulation and $\mathrm{N}$ fixation to the selected plant species (Araújo et al., 2007).

Rosa et al. (2007a) evaluated the toxicity of aqueous extracts of both fresh and stabilized textile sludge using a battery of short-term assays, employing test organisms at three different trophic levels of the aquatic ecosystems (bacteria, algae and fish). They also used plants and earthworms as representative terrestrial species. The sludge was collected at a textile industry that treats its effluents at a tertiary level via anaerobic digestion. The authors observed that the stabilized sludge caused an increase in algae growth, while the fresh sludge led to a decrease in growth at almost all tested concentrations. The authors suggested that the toxic organic compounds were degraded during the stabilization process. In the tests with cabbage (B. oleracea L. var. capitata), the results were similar to the ones with algae. There was an increase in fresh biomass in the plants exposed to the stabilized sludge, and an inhibitory effect for those exposed to fresh sludge. Regarding seed germination, fresh sludge showed also an inhibitory effect. According to the authors, the high $\mathrm{C}: \mathrm{N}$ ratio and the low levels of toxic organic compounds in the stabilized sludge seem to be responsible for the observed beneficial effects (Rosa et al., 2007a).

In another study, Rosa et al. (2007b) investigated the toxicity of both stabilized and fresh sludge using the test with E. sativa L. (rocket leaves), evaluating biomass production and germination rate. The stabilized sludge induced an increase in the biomass at concentrations above $12.5 \%$, while the fresh sludge samples showed inhibitory effects at the same concentrations. For seed germination fresh sludge showed inhibitory effects at a concentration of $50 \%$. The toxicity difference between the fresh and stabilized sludge samples seems also to be related to the nutrient content and the presence of toxic organic compounds (Rosa et al., 2007a). Based on these results, the authors suggest that textile sludge should be composted and stabilized before applied in agriculture (Rosa et al., 2007b).

El Hammadi et al. (2007) evaluated the phytotoxicity of textile sludge and its compost, using sunflower seeds $(H$. annuus L.). Both fresh and composted sludge samples showed phytotoxicity, although the compost was relatively less toxic. In this study, the authors also concluded that root growth is a more sensitive endpoint than seed germination for the toxicity evaluation of this type of sample.

Kočí et al. (2010) recommended a battery of phytotoxicity tests to evaluate solid wastes and contaminated soil including both aquatic tests of waste elutriates (using the algae Desmodesmus subspicatus along with the aquatic plant Lemna minor), in addition to testing the solid samples on L. sativa and Hordedeum vulgare (dicotyledonous and monocotyledonous respectively).

\section{Aquatic organisms}

Textile sludge samples were evaluated with $D$. magna (microcrustacean) (Rodriguez \& Pawlowsky, 2007; Rosa et al., 2007a), P. reticulata (fish) (Rosa et al., 2007a), B. plicatili (rotifer) (Park et al., 2005) and Hydra attenuata (cnidarian) (Dellamatrice \& Monteiro, 2006b).

Rodriguez \& Pawlowsky (2007) employed D. magna in the evaluation of acute toxicity of aqueous extracts of a sludge sample produced by the treatment of effluents from the dyeing process (classified as II A - non-inert; Brazilian guideline NBR 10004) and a sample from textile mills treatment plant (classified as II B - inert; NBR 10004) (ABNT, 2004). The results were expressed using a toxicity factor (TF), defined as the lower sample dilution that does not cause more than $10 \%$ immobility to the exposed organisms. For the sample originated from the dyeing process, TF was equal to 1 , and for that from the textile mill, TF was 4 . The authors considered TF values of 1 as indicative of lack of toxicity, while values above 1 indicate toxicity to D. magna. Thus, only the sludge class II B was considered toxic (Rodriguez \& Pawlowsky, 2007).

Aqueous extracts obtained from fresh and stabilized sludge were tested by Rosa et al. (2007a). The aqueous extract from fresh sludge proved to be more toxic for D. magna than the one from the stabilized sludge. For the fishes, the result was similar to the one with the Daphnia, although the stabilized sludge sample did not show any toxicity ( $24 \mathrm{~h}$ of exposure) (Rosa et al. 2007a).

Park et al. (2005) employed the marine rotifer B. plicatilis in the evaluation of eleven sludge aqueous extracts of different origins (urban, industrial, rural, and livestock) and two samples from a textile industry. The authors obtained the extracts from all samples via solid/liquid extraction in a 1:10 (w/v - sludge:filtered sea water). The $24 \mathrm{~h}$ rotifer mortality test was conducted using Rotoxkit M (Microbiotests Inc., Belgium) with neonates. The rotifer population growth rate (PGR) endpoint was estimated using a parthenogenic female. The number of rotifer individuals was counted after $48 \mathrm{~h}$ and the PGR was calculated as the following: $r=\left(\operatorname{lnN}_{\mathrm{t}}-\ln \mathrm{n}_{\mathrm{o}}\right) / \mathrm{t}$ $\left(\mathrm{r}=\right.$ PGR, $\mathrm{N}_{\mathrm{t}}=$ number of organisms at time $\mathrm{t}, \mathrm{N}_{\mathrm{o}}=$ initial population density, $\mathrm{t}=$ hour).

The authors observed high toxicity to rotifers $\left(\mathrm{LC}_{50} 24 \mathrm{~h}\right.$ of 2.9) for one of the two textile sludge tested. High toxicity was also observed for the PGR endpoint. Rotifer PGR was less sensitive than the neonate mortality test in the evaluation of the tested samples. The authors concluded that the mortality test using $B$. plicatilis was less sensitive than the $V$. fischeri bioassay (Park et al., 2005).

The sludge samples evaluated by Dellamatrice \& Monteiro (2006b) originated from a municipal treatment plant that receives a mixture of wastewaters composed by $1 / 4$ from household effluents and $3 / 4$ from the effluents of 43 textile facilities that use anthraquinone and indigoid dyes. The authors treated the sludge with Pleurotus ostreatus and Pleurotus sajor-caju in order to remove the color. The 
treatment increased the toxicity of the aqueous extracts samples for $H$. attenuata.

\section{Bacteria}

The development tests employing bacteria aimed mainly at reducing both costs and duration of the experiments. The bioluminescence assay with $V$. fischeri is considered by many researchers as the most sensitive one for a wide range of chemicals when compared to other bacterial assays employing endpoints such as inhibition of nitrification, respiration, luminescence and enzymatic ATP inhibition (Girotti et al., 2008).

Rosa et al. (2007a) employed the $V$. fischeri acute toxicity test in their test battery. The aqueous extracts of stabilized sludge samples did not show toxicity, although the aqueous extracts of fresh sludge showed low toxicity with $50 \%$ effective concentration values $\left(\mathrm{EC}_{50}\right)$ greater than $80 \%$.

Park et al. (2005) evaluated the toxicity of the same samples described above using $V$. fischeri. The sludge from the textile facility was the one that showed the highest acute toxicity $\left(\mathrm{EC}_{50}=21.84 \%\right)$, similar to the result obtained with the marine rotifer.

Rodrigres \& Pawlowsky (2007) employed $V$. fischeri in order to evaluate the toxicity of aqueous extracts of industrial solid waste samples classified as II A and II B according to ABNT (2004). The two samples from the textile facilities presented TFs of 8 and 64 respectively. They were the most toxic among all the sludge tested. The authors observed that $D$. magna and $V$. fischeri showed similar sensitivity, although $V$. fischeri proved to be more sensitive to the textile plant sludge.

The mutagenic activity of sludge samples collected at six different textile mills having dyeing units was evaluated by Umbuzeiro et al. (2004) using the Salmonella/microsome test employing the TA98 and TA100 strains both in the absence and presence of the S9. The authors also evaluated the efficiency of the solvent extractor, and methanol proved to be the most efficient one at recovering the mutagenic compounds present in the sludge. At least one sample from each evaluated facility showed mutagenic activity. Positive results were observed only in the presence of S9. Only two treatment plants showed samples with mutagenic response both in the presence and absence of S9. The authors suggested that the mutagenic activity detected with the T98 strain is probably related to the presence of dyes, such as those belonging to the class of aminobenzenes or the aromatic amines.

Mathur et al. (2007) also used the Salmonella/microsome to analyze the mutagenicity of sludge samples collected at a treatment plant that treats effluents from 487 small and medium textile facilities. The sludge originated in the chemical and biological treatments were separately tested. All the sludge samples from the chemical treatment showed mutagenic activity for the TA98 and TA100 strains. Sludge from the biological treatment were the most mutagenic ones. The authors also suggested that the observed mutagenic activity could be related to the presence of dyes coming from the dyeing process.

Mathur et al. (2007) suggest that the Salmonella assay should be employed as an initial screening test for evaluating the possibility of application of the sludge on soil. The use of other assays for the evaluation of genotoxicity should also be considered, especially those employing higher plants, such as the micronucleous test with Tradescantia sp. (Mielli et al., 2009) and the Allium cepa test (Leme \& Marin-Morales, 2009).

\section{Terrestrial invertebrates}

Earthworms are exposed to toxicants in contaminated soils via direct contact, ingestion of water phase and solid particles, and also via food chain. In the test battery conducted by Rosa et al. (2007a), they carried out toxicity tests with the earthworm $E$. foetida, using adult individuals of at least two months old. The tests were conducted in a culture chamber with constant light intensity at $20{ }^{\circ} \mathrm{C}$. The organisms were exposed to a control soil and to dilutions of fresh and stabilized sludge diluted in this soil at proportions ranging from 6.2 to $50 \%$. Fresh sludge did not show toxicity. Stabilized sludge was also not toxic and it increased the organism biomass as already observed for the algae test. The authors suggest that the stabilized sludge may be used in the restoration of a non-productive forest soil due to the fertilizer/conditioner potential (Rosa et al., 2007a).

Natal-da-Luz et al. (2009) highlighted the efficiency of the use of earthworms for the evaluation of toxicity of sludge from urban, olive-processing, and electroplainig industries. The use of other soil organisms, such as springtails, may be also an interesting alternative for the evaluation of this kinds of sludge.

\section{Mammals}

Exposure to chemical compounds can produce a variety of adverse effects including chromosomal changes, mutations, sperm abnormalities, early or late foetal loss, still births, decrease birth weights, altered sex ratio, birth defects and childhood malignancies (Soni et al., 2008). Soni et al. (2008) evaluated the toxicity of samples of chemically and biologically treated sludge collected at wastewater treatment plant that only treats effluent from different textile facilities on the reproduction of the Swiss albino mice. The sludge aqueous extracts were diluted in water, homogenized, filtered, and given to pregnant females between the sixth and fifteenth pregnancy day at $1: 10$ and $1: 100$ dilutions.

The samples presented maternal toxicity at the tested doses. The toxic symptoms were muscular tremors, ataxia, convulsions, hypersalivation, lacrimation and restlessness. The higher concentrations induced a reduction in the average weight gain by dams during gestation, but there was no mortality of the dams. The fetuses showed external malformations, such as subcutaneous edema and open eyelids. Free-hand razor sections of the brain region showed hydrocephaly, involving chiefly the lateral ventricles. Alzarin stained skeletons of the fetuses of both dose groups evidenced reduced ossification of skull bones, reduced number of ribs and sternebral defects. The most severe effects were observed at the higher sludge concentrations (Soni et al., 2008). The authors suggest that the observed toxic effects may be related to the presence of metals, organic compounds or even to the lack of some essential elements, such as calcium 
and magnesium in the sludge dilutions (Soni et al., 2008). More tests employing mammals are required aiming at obtaining more information on the possible effects of textile sludge in different organs and systems.

Table 1 presents a summary of the toxicity tests employed and the main results found in the studies evaluating textile sludge samples obtained in this literature search. Several authors suggested different toxicity tests batteries for the evaluation of wastes (Pandard et al., 2006; Wilke et al., 2008; Kočí et al., 2010) but for textile sludge it seems too soon to suggest a test battery because of the small amount of data.

\section{CONCLUSIONS}

There are few studies about the toxicity evaluation of textile sludge in the peer reviewed literature although the great amount of waste generated by this activity and the need of sustainable disposal practices.
Sample preparation techniques represent an important step of the ecotoxicological evaluation of any environmental samples and if they are standardized they allow the possibility of comparison among different studies. In the case of textile sludge no standardized procedure has been already proposed.

Higher plants were the most commonly employed organisms in the surveyed articles and the composting processes seems to be effective for reducing or completely eliminating the phytotoxicity of the samples. Because of the scarce information on the use of algae for the toxicity evaluation of textile sludge, more data are required to verify its applicability.

Among the aquatic organisms, the most commonly employed was D. magna, and its sensitivity seems to be relatively higher than the other organisms that were used.

$V$. fischeri showed higher sensitivity to the toxicants present in sludge of a textile origin, when compared to the other

Table 1 - Summary of studies about the evaluation of toxicity of textile sludge (adapted and complemented from Gomes et al. (2008).

\begin{tabular}{|c|c|c|c|c|c|}
\hline Species & Endpoint & Sample & Sample preparation & Results & Ref. \\
\hline \multicolumn{6}{|c|}{ Bioassays with plants and algae } \\
\hline $\begin{array}{l}\text { Soy and wheat - } \\
\text { seeds }\end{array}$ & $\begin{array}{c}\text { Seed germination and root } \\
\text { elongation }\end{array}$ & $\begin{array}{c}\text { Fresh and composted textile } \\
\text { sludge ( } 90 \text { days of composting) }\end{array}$ & Aqueous extracts & $\begin{array}{c}\text { It was not observed toxicity for the } \\
\text { composted sludge samples. Fresh textile } \\
\text { sludge showed toxic effects for both } \\
\text { species, wheat being the most sensitive } \\
\text { one. }\end{array}$ & $\begin{array}{l}\text { Araújo et al. } \\
\qquad(2001)\end{array}$ \\
\hline $\begin{array}{l}\text { Soy (IAC Foscari) } \\
\text { and wheat (IAC 305) - } \\
\text { seedling }\end{array}$ & $\begin{array}{c}\text { Total dry matter, height of } \\
\text { the aerial part, root length, } \\
\text { chlorophyll content, peroxidase } \\
\text { activity }\end{array}$ & $\begin{array}{l}\text { Textile sludge composted with } \\
\text { wood shaves }\end{array}$ & $\begin{array}{l}\text { Composted sludge plus water } \\
\text { and Hoagland solution (II) }\end{array}$ & $\begin{array}{l}\text { There was a reduction of dry matter, } \\
\text { height of the aerial part, root length } \\
\text { and chlorophyll content for both } \\
\text { species. Increase in the peroxidase } \\
\text { activity. Higher concentrations led to } \\
\text { the occurrence of toxicity signals in } \\
\text { the leaves. }\end{array}$ & $\begin{array}{l}\text { Araújo et al. } \\
\qquad(2005)\end{array}$ \\
\hline $\begin{array}{l}\text { Soy (IAC Foscari) } \\
\text { and wheat (IAC 305) - } \\
\text { seedling }\end{array}$ & $\begin{array}{c}\text { Germination, total dry matter, } \\
\text { height of the aerial part, root } \\
\text { length, }\end{array}$ & $\begin{array}{l}\text { Composted textile sludge ( } 90 \\
\text { days of composting) }\end{array}$ & $\begin{array}{l}\text { Aqueous extracts (I) and } \\
\text { composted sludge plus } \\
\text { Hoagland solution (II) }\end{array}$ & $\begin{array}{l}\text { For the aqueous extracts (experiment } \\
\text { I) they did not observe toxicity. For the } \\
\text { samples added with Hoagland solution } \\
\text { (experiment II) there was a decrease of } \\
\text { total dry matter, length of the aerial part } \\
\text { and of the roots. }\end{array}$ & $\begin{array}{l}\text { Araújo \& } \\
\text { Monteiro } \\
(2005)\end{array}$ \\
\hline Soy and cowpea beans & $\begin{array}{l}\text { Root and shoot dry matter, } \\
\text { nitrogen }(\mathrm{N}) \text { fixation, glutamine } \\
\text { synthetase and leghemoglobin } \\
\text { content and nodulation. }\end{array}$ & $\begin{array}{l}\text { Textile sludge composted with } \\
\text { wood shaves }\end{array}$ & $\begin{array}{l}\text { Composted sludge added to } \\
\text { yellow podzolic soil }\end{array}$ & $\begin{array}{l}\text { There was a reduction in bud and } \\
\text { root dry mass for both species. } \\
\text { Activity of glutamine synthetase } \\
\text { and leghemoglobin content were not } \\
\text { affected. There was no toxicity effect on } \\
\text { N fixation. }\end{array}$ & $\begin{array}{l}\text { Araújo et al. } \\
\qquad(2007)\end{array}$ \\
\hline $\begin{array}{l}\text { Eruca sativa } . L \\
\text { (rocket.) }\end{array}$ & Shoot dry matter. & $\begin{array}{c}\text { Fresh and stabilized textile } \\
\text { sludge }\end{array}$ & Aqueous extracts & $\begin{array}{l}\text { Both types of sludge showed toxicity. } \\
\text { Fresh sludge proved to be more toxic } \\
\text { than the stabilized one }\end{array}$ & $\begin{array}{l}\text { Rosa et al. } \\
\text { (2007b) }\end{array}$ \\
\hline $\begin{array}{l}\text { Scenedesmus } \\
\text { subspicatus } \text { (algae) e } \\
\text { Brassica oleracea L. } \\
\text { var. capitata (cabbage) }\end{array}$ & $\begin{array}{l}\text { Algae - growth inhibition. } \\
\text { Cabbage - germination and } \\
\text { biomass production }\end{array}$ & $\begin{array}{l}\text { Fresh and stabilized textile } \\
\text { sludge }\end{array}$ & $\begin{array}{l}\text { Aqueous extracts for the } \\
\text { algae and sludge treated } \\
\text { through anaerobic digestion } \\
\text { at a tertiary level for the } \\
\text { cabbage }\end{array}$ & $\begin{array}{l}\text { Fresh sludge showed toxic effects for } \\
\text { the cabbage in both parameters. For } \\
\text { the algae only the fresh sludge showed } \\
\text { toxicity. It was not observed toxicity for } \\
\text { the stabilized sludge. }\end{array}$ & $\begin{array}{l}\text { Rosa et al. } \\
\text { (2007a) }\end{array}$ \\
\hline $\begin{array}{l}\text { Helianthus annuus } L . \\
\text { (sunflower) }\end{array}$ & $\begin{array}{c}\text { Seed germination and root } \\
\text { elongation }\end{array}$ & $\begin{array}{l}\text { Fresh and composted textile } \\
\text { sludge }\end{array}$ & $\begin{array}{c}\text { Layers of fresh and } \\
\text { composted sludge covered } \\
\text { with filter paper }\end{array}$ & $\begin{array}{l}\text { Both the fresh and the composted } \\
\text { sludge showed phytotoxicity, the last } \\
\text { one being less toxic. Root elongation } \\
\text { was the most sensitive parameter. }\end{array}$ & $\begin{array}{l}\text { El Hammadi } \\
\text { et al. (2007) }\end{array}$ \\
\hline \multicolumn{6}{|c|}{ Bioassays with aquatic organisms } \\
\hline $\begin{array}{l}\text { Daphnia magna } \\
\text { (microcrustacean) }\end{array}$ & Immobilization & $\begin{array}{l}\text { Sludge from dyeing waste } \\
\text { treatment and from textile } \\
\text { industry waste treatment }\end{array}$ & Aqueous extracts & Both samples showed toxicity. & $\begin{array}{c}\text { Rodrigues \& } \\
\text { Pawlowsky } \\
\text { (2007) }\end{array}$ \\
\hline $\begin{array}{l}\text { Daphnia magna } \\
\text { (microcrustacean) e } \\
\text { Poecila reticulata (fish) }\end{array}$ & Mortality/ Immobilization & $\begin{array}{c}\text { Fresh and stabilized textile } \\
\text { sludge }\end{array}$ & Aqueous extracts & $\begin{array}{l}\text { Both types of sample showed toxicity } \\
\text { for Daphnia magna. Only the fresh } \\
\text { sludge was toxic for the fish. }\end{array}$ & $\begin{array}{l}\text { Rosa et al. } \\
\text { (2007a) }\end{array}$ \\
\hline $\begin{array}{l}\text { Brachionus plicatilis } \\
\text { (rotifer) }\end{array}$ & $\begin{array}{l}\text { Mortality and inhibition of } \\
\text { population growth }\end{array}$ & $\begin{array}{l}\text { Sludge from dyeing waste } \\
\text { treatment and from textile } \\
\text { industry waste treatment }\end{array}$ & $\begin{array}{l}\text { Aqueous extracts obtained } \\
\text { with marine water }\end{array}$ & $\begin{array}{l}\text { Both parameters indicated a high } \\
\text { toxicity of the sludge samples from the } \\
\text { dyeing industry. }\end{array}$ & $\begin{array}{l}\text { Park et al. } \\
\quad(2005)\end{array}$ \\
\hline
\end{tabular}




\begin{tabular}{|c|c|c|c|c|c|}
\hline \multicolumn{6}{|c|}{ Bioassays with bacteria } \\
\hline Vibrio fischeri & Luminescence inhibition & $\begin{array}{l}\text { Sludge from dyeing waste } \\
\text { treatment and from textile } \\
\text { industry waste treatment }\end{array}$ & Aqueous extracts & $\begin{array}{l}\text { Only the sludge sample from the textile } \\
\text { industry showed toxicity. }\end{array}$ & $\begin{array}{c}\text { Rodrigues \& } \\
\text { Pawlowsky } \\
(2007)\end{array}$ \\
\hline Vibrio fischeri & Luminescence inhibition & $\begin{array}{l}\text { Fresh and stabilized textile } \\
\text { sludge }\end{array}$ & Aqueous extracts & $\begin{array}{l}\text { Only the fresh sludge showed toxic } \\
\text { effects. }\end{array}$ & $\begin{array}{l}\text { Rosa et al. } \\
(2007 \mathrm{a})\end{array}$ \\
\hline Vibrio fischeri & Luminescence inhibition & $\begin{array}{l}\text { Sludge from dyeing waste } \\
\text { treatment and from textile } \\
\text { industry waste treatment }\end{array}$ & $\begin{array}{l}\text { Aqueous extracts obtained } \\
\text { with marine water }\end{array}$ & $\begin{array}{l}\text { They observed high toxicity of the } \\
\text { sludge sample from the dyeing industry. }\end{array}$ & $\begin{array}{l}\text { Park et al. } \\
\quad(2005)\end{array}$ \\
\hline $\begin{array}{l}\text { Salmonella } \\
\text { typhimurium } \\
\text { (TA98 and TA100) }\end{array}$ & $\begin{array}{l}\text { Mutagenicity (Salmonella/ } \\
\text { microsome test) }\end{array}$ & $\begin{array}{l}\text { Sludge from dyeing waste } \\
\text { treatment }\end{array}$ & Organic extracts (methanol) & $\begin{array}{c}\text { Out of the } 15 \text { analyzed samples, } 12 \\
\text { showed positive results, especially with } \\
\text { the TA98 lineage in the presence of } \\
\text { metabolic activation (S9) }\end{array}$ & $\begin{array}{l}\text { Umbuzeiro } \\
\text { et al. } \\
(2004)\end{array}$ \\
\hline $\begin{array}{l}\text { Salmonella } \\
\text { typhimurium } \\
\text { (TA98 and TA100) }\end{array}$ & $\begin{array}{l}\text { Mutagenicity (Salmonella/ } \\
\text { microsome test) }\end{array}$ & $\begin{array}{l}\text { Sludge from the biological and } \\
\text { chemical treatment of several } \\
\text { textile companies }\end{array}$ & Aqueous extracts & $\begin{array}{c}\text { All samples of biological and chemical } \\
\text { sludge showed mutagenic activity for } \\
\text { the TA98 and TA100 strains }\end{array}$ & $\begin{array}{l}\text { Mathur et al. } \\
\text { (2007) }\end{array}$ \\
\hline \multicolumn{6}{|c|}{ Bioassays with terrestrial invertebrates } \\
\hline $\begin{array}{l}\text { Eisenia foetida } \\
\text { (earthworms) }\end{array}$ & Biomass production & $\begin{array}{l}\text { Fresh and stabilized textile } \\
\text { sludge }\end{array}$ & $\begin{array}{l}\text { Sludge added to yellow-red } \\
\text { podzolic soil }\end{array}$ & $\begin{array}{l}\text { Toxicity was not observed for both } \\
\text { samples. }\end{array}$ & $\begin{array}{l}\text { Rosa et al. } \\
\text { (2007a) }\end{array}$ \\
\hline \multicolumn{6}{|c|}{ Bioassays with mammals } \\
\hline Swiss albino mice & $\begin{array}{l}\text { Maternal toxicity, teratogenicity } \\
\text { and embryotoxicity }\end{array}$ & $\begin{array}{l}\text { Biologically and chemically } \\
\text { treated sludge diluted in water }\end{array}$ & Solubilized samples & $\begin{array}{l}\text { They observed maternal toxicity, } \\
\text { with no deaths. They could observe } \\
\text { embryotoxic and teratogenic effects in } \\
\text { the fetuses, and these were stronger at } \\
\text { the highest sludge concentration. }\end{array}$ & $\begin{array}{l}\text { Soni et al. } \\
\quad(2008)\end{array}$ \\
\hline
\end{tabular}

organisms. Its high sensitivity, relative low cost and rapidity makes it a good choice for textile sludge hazard evaluation.

Genotoxicity seems to be an important endpoint because positive results were obtained for the majority of the tested samples and because of Salmonella/microsome assay simplicity and relative low cost could be also a good option for a textile sludge battery tests.

In theory, earthworms play an important role in soil biological process therefore they could be good candidates to be included in a test battery to evaluate textile sludge for agricultural purposes. Again, because of the scarce information on the use of earthworms for the toxicity evaluation of textile sludge more data are required to verify its actual applicability.

Significant toxic effects on the reproduction were observed after the exposure of mammals to textile sludge samples. Those results are of great concern and suggest that more studies are required in order to evaluate the possible risks associated to wildlife and human health.

Efforts are being undertaken with the objective of establishing a reliable battery of bioassays for ecotoxicological evaluation of hazardous wastes, yet still cannot establish what the best combination of bioassays and endpoints for this purpose.

Acknowledgments: The authors thank Dr Gisela de Aragão Umbuzeiro for helpful comments on this manuscript. The authors wish to thank the FAPEMIG (Fundação de Amparo à Pesquisa do estado de Minas Gerais) for their economic support.

\section{REFERENCES}

ABNT, Associação Brasileira de Normas Técnicas, 2004, NBR 10004: Resíduos sólidos-Classificação. ABNT, Rio de Janeiro, 71p.

ABREU, M. C. S., SILVA-FILHO, J. C. L., OLIVEIRA, B. C. \& HOLANDA-JÚNIOR F. L., 2008, Perfis estratégicos de conduta social e ambiental: estudos na indústria têxtil nordestina. Gest. Prod., 15:159-172. doi: 10.1590/S0104-530X2008000100014

ALI, N. A., ATER, M., SUNAHARA, G. I. \& ROBIDOUX, P. Y., 2004, Phytotoxicity and bioaccumulation of copper and chromium using barley (Hordeum vulgare L.) in spiked artificial and natural forest soils. Ecotoxicol. Environ. Saf., 57:363-374. doi:10.1016/S0147-6513(03)00074-5

ARAÚJO, A. S. F. \& MONTEIRO, R. T. R., 2005, Plant bioassay to assess toxicity of textile sludge compost. Sci. Agric., 62:286-290. doi: 10.1590/S0103-90162005000300013

ARAÚJO, A. S. F., MONTEIRO, R. T. R. \& CARDOSO P. F., 2005, Composto de lodo têxtil em plântulas de soja e trigo. Pesq. agropec. bras., 40:549-554. doi: 10.1590/S0100204X2005000600004

ARAÚJO, A. S. F., MONTEIRO, R. T. R. \& CARDOSO, P. F., 2007, Effect of composted textile sludge on growth, nodulation and nitrogen fixation of soybean and cowpea. Bioresour. Technol., 98:1028-1032. doi:10.1016/j.biortech.2006.04.028

ARAÚJO, A. S. F., SAHYOUN, F. K. \& MONTEIRO, R. T. R., 2001, Evaluation of toxicity of textile sludge compost on seed germination and root elongation of soybean and wheat. Rev. Ecossistema, 26:117-119.

ARSLAN-ALATON, I. \& ALATON, I., 2007, Degradation of xenobiotics originating from the textile preparation, dyeing and finishing industrial using ozonation and advanced oxidation. Ecotoxicol. Environ. Saf., 68:98-107. doi:10.1016/j. ecoenv.2006.03.009

BALAN, D. S. L. \& MONTEIRO, R. T. R., 2001, Decolonization of textile indigo dye by ligninolytic fungi. J. Biotechnol., 89:141145. doi:10.1016/S0168-1656(01)00304-2

BYL, T. D., SUTTON, H. D. \& KLAINE, S. J., 1994, Evaluation of peroxidase as a biochemical indicator of toxicity chemical exposure in the aquatic plant Hydrilla verticullata, Royle. Environ. Toxicol. Chem., 13:509-515. doi: 10.1002/etc.5620130322

CELEBI, S. \& KENDIR, S., 2002, Toxicity assessment of a dye industry treatment sludge. Waste Manage. Res., 20:541-545. doi: 10.1177/0734242X0202000608

DELlAMATRICE, P. M. \& MONTEIRO, R. T. R., 2006a, Decolorization and Toxicity of municipal waste by horseradish (Cochlearia armoracia). Quim. Nova, 29: 419-421. doi: 10.1590/ S0100-40422006000300003 
DELLAMATRICE, P. M. \& MONTEIRO, R. T. R., 2006b, Toxicidade de resíduos têxteis tratados por microorganismos. $J$. Braz. Soc. Ecotoxicol., 1:63-66. doi: 10.5132/jbse.2006.01.013

El HAMMADI, M. A., TRABELSI, M. \& HANCHI, B., 2007, Phytotoxicity of Tunisian municipal and textile sludges compared to the produced compost. Asian J. Agri. Res., 1:86-91. doi: 10.3923 /ajar.2007.86.91

EN 14735, 2005, Characterization of waste - preparation of waste samples for ecotoxicity tests.

GIROTTI, S., FERRI, E. N., FUMO, M. G. \& MAIOLINI, E., 2008, Monitoring of environmental pollutants by bioluminescent bacteria. Anal. Chim. Acta, 608:2-29. doi:10.1016/j. aca.2007.12.008

GOMES, L. S., SILVA, F. A., BARBOSA, S. \& KUMMROW, F., 2008, Bioensaios usados para a avaliação da toxicidade de lodos gerados no tratamento de efluentes de indústrias têxteis. HOLOS environ., 8. Available in: http://cecemca.rc.unesp.br/ojs/index. $\mathrm{php} /$ holos/article/view/1683/1476

HEWITT, L. M. \& MARVIN, C. H., 2005, Analytical methods in environmental effects-directed investigation of effluents. Mutat. Res., 589:208-232. doi:10.1016/j.mrrev.2005.02.001

KAPANEN, A. \& ITÄVAARA, M., 2001, Ecotoxicity tests for compost applications. Ecotoxicol. Environ. Saf., 49:1-16. doi:10.1006/eesa.2000.1927

KAPUSTKA, L. A., 1997. Selection of phytotoxicity tests for use in ecological risk assessments, pp. 516-548. In: W. Wang, J. M. \& Gorsuch, D. Hughes (orgs.), Plants for environmental studies, CRC Press, New York.

KOČÍ, V., MACOVÁ, K., KULOVANÁ, M. \& VOSÁHLOVÁ, S., 2010, Phytotoxicity tests of solid wastes and contaminated soil in the Czech Republic. Environ. Sci. Pollut. Res., 17:611-623. doi: 10.1007/s11356-009-0214-5

KUNZ, A., PERALTA-ZAMORA, P., MORAES, S. G. \& DURÁN, N., 2002, Novas tendências no tratamento de efluentes têxteis. Quim. Nova, 25:78-82. doi: 10.1590/S010040422002000100014

LEME, D. M. \& MARIN-MORALES, M. A., 2009, Allium cepa test in environmental monitoring: a review on its application. Mutat. Res., 682:71-81. doi:10.1016/j.mrrev.2009.06.002

MATHUR,N.,BHATNAGAR,P.,MOHAN,K.,BAKRE,P.,NAGAR, P. \& BIJARNIA, M., 2007, Mutagenic evaluation of industrial sludge from common effluent treatment plant. Chemosphere, 67:1229-1235. doi:10.1016/j.chemosphere.2006.10.073

MIELLI, A. C., MATTA, M. E. M., NERSESYAN, A., SALDIVA, P. H. N. \& UMBUZEIRO, G. A., 2009, Evaluation of the genotoxicity of treated urban sludge in the Tradescantia micronucleus assay. Mutat. Res., 672:51-54. doi:10.1016/j. mrgentox.2008.09.007

NATAL-da-LUZ, T., TIDONA, S., JESUS, B., MORAIS, P. V. \&
SOUSA, J. P., 2009, The use of sewage sludge as soil amendment. The need for an ecotoxicological evaluation. J. Soils Sediments, 9:246-260. doi: 10.1007/s11368-009-0077-x

PANDARD, P., DEVILLERS, J., CHARISSOU, A., POULSEN, V., JOURDAIN, M., FÉRARD, J., GRAND, C. \& BISPO, A., 2006, Selecting a battery of bioassays for ecotoxicological characterization of wastes. Sci. Total Environ., 363:114-125. doi:10.1016/j.scitotenv.2005.12.016

PARK, G. S., CHUNG, C. S., LEE, S. H., HONG, G.-H., KIM, S. H., PARK, S. Y., YOON, S. J. \& LEE, S. M., 2005, Ecotoxicological Evaluation of Sewage Sludge Using Bioluminescent Marine Bacteria and Rotifer. Ocean Sci. J., 40:91-100. doi: 10.1007/ BF03028589

PARVEZ, S., VENKATARAMAN, C. \& MUKHERJI, S., 2006, A review on advantages of implementing luminescence inhibition test (Vibrio fischeri) for acute toxicity prediction of chemicals. Environ. Int., 32:265-268. doi:10.1016/j.envint.2005.08.022

RODRIGUES, N. L. V. B. \& PAWLOWSKY, U., 2007, Testes de toxicidade aguda através de bioensaios no extrato solubilizado dos resíduos Classe II A - Não inertes e Classe II B - Inertes. Eng. Sanit. Ambent., 12:8-16. doi: 10.1590/S141341522007000100002

ROSA, E. V. C., GIURADElli, T. M., CORRÊA, A. X. R., RÖRIG, L. R., SSHWINGEL, P. R., RESGALLA-Jr., C. \& RADETSKI, C. M., 2007a, Ecotoxicological evaluation of the short term effects of fresh and stabilized textile sludges before application in forest soil restoration. Environ. Pollut., 146:463469. doi:10.1016/j.envpol.2006.07.005

ROSA, E. V. C., MATERA, L., SOUZA-SIERRA, M. M., RÖRIG, L. R., VIEIRA, L. M. \& RADETSKI, C. M., 2007b, Textile sludge application to non-productive soil: Physico-chemical and phytotoxicity aspects. Ecotoxicol. Environ. Saf., 68:91-97. doi:10.1016/j.ecoenv.2006.06.006

SHARMA, K. P., SHARMA, S., SHARMA, S., SINGH, P. K., KUMAR, S., GROVE, R.\& SHARMA,P.K., 2007, A comparative study on characterization of textile waste waters (untreated and treated) toxicity by chemical and biological tests. Chemosphere, 69:48-54. doi:10.1016/j.chemosphere.2007.04.086

SONI, H. I., BAKER, P. P. \& BHATNAGAR P., 2008, Assessment of teratogenecity and embryotoxicity of sludge from textile industries at Pali (India) in Swiss albino mice exposed during organogenic period. J. Environ. Biol., 29:965-969.

UMBUZEIRO, G. A., ROUBICEK, R. A., OliVEIRA, D. P., MURAKAMI, D., COIMBRÃO, C. A. \& STRAUS, E. L., 2004, Mutagenic activity of sludge samples generated in dyeing processing textile plants. Rev. Bras. Toxicol., 17:29-36.

WILKE, B. M., RIEPERT, F., KOCH, C. \& KÜHNE, T., 2008, Ecotoxicologicalcharacterization of hazardous wastes. Ecotoxicol. Environ. Saf., 70:283-293. doi:10.1016/j.ecoenv.2007.10.00 